\title{
The Effect of Money Supply, Exchange Rate, and Interest Spread toward the Performance of Stock Market in Malaysia
}

\author{
Yeoh Kai Qing ${ }^{1}$, Suhal Kusairi²,* \\ ${ }^{1,2}$ Faculty of Business, Economics and Social Development \\ Universiti Malaysia Terengganu, 21030 Kuala Nerus, Terengganu, Malaysia \\ ${ }^{1}$ kaiqing31@gmail.com \\ ${ }^{2}$ suhal@umt.edu.my
}

Received 31 August 2019, Revised 18 September 2019, Accepted 25 September 2019

\begin{abstract}
The stock market has become a significant role in the economy and has attracted investor's attention, as it is to generate funds and make an investment decision for companies and investors as well. Therefore, the objective of this study is to study the effect of the money supply, exchange rate, interest spread and stock market in the short and long run and volatility issue. The study employed monthly data, from January 1997 to August 2018. Method analysis is the Autoregressive distributed lag (ARDL) and GARCH model. The findings stated that the money supply, real effective exchange rate, interest spread, had a long-run effect on the performance of the stock market. Money supply and the real effective exchange rate had a positive effect on the stock market performance in the short run. Conversely, the interest spread showed a negative influent on the stock market performance in the short run. The volatility indicated a high persistence between the money supply, real effective exchange rate, interest spread and stock market (KLCI). The implication of the study is the investors or policymakers should take account the changes of interest rate and exchange rate before making stock investment or policy to stabilize the stock market performance.
\end{abstract}

Keywords: Performance, Money Supply, Real Effective Exchange Rate (REER), Interest Spread

\begin{abstract}
Abstrak - Pasar saham telah berperan penting dalam perekonomian dan telah menarik perhatian investor, karena dapat menghasilkan dana dan membuat keputusan investasi untuk perusahaan dan investor juga. Oleh karena itu, tujuan dari penelitian ini adalah untuk mempelajari pengaruh jumlah uang yang beredar, nilai tukar, spread bunga dan pasar saham dalam jangka pendek dan jangka panjang dan masalah volatilitas. Studi ini menggunakan data bulanan, dari Januari 1997 hingga Agustus 2018. Metode analisis yang digunakan adalah Autoregressive Distributed Lag (ARDL) dan model GARCH. Temuan menyatakan bahwa jumlah uang beredar, nilai tukar riil efektif, dan penyebaran bunga, memiliki efek jangka panjang pada kinerja pasar saham. Jumlah uang beredar dan nilai tukar efektif riil memiliki efek positif pada kinerja pasar saham dalam jangka pendek. Sebaliknya, spread bunga menunjukkan pengaruh negatif pada kinerja pasar saham dalam jangka pendek. Volatilitas mengindikasikan persistensi yang tinggi antara jumlah uang beredar, nilai tukar riil efektif, spread bunga dan pasar saham (KLCI). Implikasi dari penelitian ini adalah para investor atau pembuat kebijakan harus memperhitungkan perubahan tingkat bunga dan nilai tukar sebelum melakukan investasi saham atau kebijakan untuk menstabilkan kinerja pasar saham.
\end{abstract}

Kata kunci: Kinerja, Jumlah Uang Beredar, Nilai Tukar Riil Nyata (REER), Spread Bunga

\section{INTRODUCTION}

Stock can be defined as securities or certificates and representing investors as part of the ownership of the company purchased as an investment while the stock market is a market that includes transactions that fully promote the share of company ownership (Fontanills \& Gentile, 2001). The stock market performance can represent the overall economic performance of a country. Nordin et al. (2016) state the funds provided through the stock market that can increase the efficiency of the capital market and provide investment opportunities. Specifically, investors can participate in trading activities in the capital market. The index of the stock market is to measures capital market performance. As the stock market index increases, capital market performance increases and economic activities such as investment also increase. The index of the stock market leads the economic activity as long as the movements of stock prices relate to fundamentals. Increase in investor wealth will lead them to make more investment in the stock market, and it will affect the market. The fluctuations in stock price reflected in the stock 
market index. Alzaid (2016) reveals that the stock market provides the best capital resource to many companies in Malaysia. The role of the stock market is to encourage fundraising and guide funds to carry out productive economic activities.

Kuala Lumpur Composite Index (KLCI) measures the stock market in Malaysia. With the adoption of the FTSE International Index method, KLCI is the benchmark index rose to a new level. The Malaysian stock market is particularly impressive. Because its unique characteristics may affect the movement patterns of the different stock price in advanced economics or other emerging economies (Rahman et al., 2009), the stock market can affect many factors. In this study, the factors are money supply M2, exchange rate and interest spread between Malaysia and the United State.

The problem statements are the stock market index is high fluctuations especially when it occur the financial crisis. Different empirical studies have achieved excellent and uncertain outcomes with the effect of money supply, exchange rate and interest spread on stock market index. Many studies focus on an evolved nation instead of developing nation. Moreover, many researches have examined the interaction among the interest rate and the performance of stock market. However, there is a research gap of the study with the interest spread. The investigator has concentrated on the interest rate but not a spread. In this research, we focus on the spread between the two countries. Investor will compare the interest rate between two countries to make whether invest in the country.

Thus, the objective of the study is to study the relationship between the money supply, exchange rate, interest spread and stock market in the short and long run. The second objective is to determine the volatility spillover effect of money supply, exchange rate and interest spread on the Malaysia stock market. This research is important to know the effect of the money supply, exchange rate and interest spread on the stock market. It helps policymakers to forecast the investor in the stock market and also what policy should make during the financial crisis. This study can give guidance for the investor to decide on the investment in the stock market.

This study is utilized the Augmented DickeyFuller (ADF) \& Phillips-Perron (PP) test to determine the variables stationary whether at level, first different or second different. After that, modeled the cointegration/bound test of the long run using ADRL. When the results show that exist long run relationship. The process will be carry by the Error Correction Model (ECM). ECM test to determine the speed of adjustment towards the dynamics of short run to long run equilibrium. Next, modeled the volatility of the stock market index using the $\mathrm{ARCH}$ and $\mathrm{GARCH}$ method. Lastly, modeled diagnostic checking such as Normality, Autocorrelation and Heteroscedasticity test and continued by CUSUM to determine the accuracy of the model.

This paper is composed of the following; the next section will focus on selected literature studies on the stock market index. Discussions will focus on previous studies either in Malaysia or abroad that examine the relationship between stock market and variables. The next discussion focused on the research methodology that included data sources and data analysis using the ARDL approach. Furthermore, the findings and conclusions will be discussed.

\section{LITERRATURE REVIEW}

Garcia and Liu (1999) stated that the improvement of the stock market is a multidimensional idea. It typically measured through the dimensions of the stock market, liquidity, volatility, capital markets integration within the international, and a few regulations within the market. Many high-return projects require long-term capital commitments with a higher risk of default and liquidity. An investor is often afraid to take on these risks. Therefore, if there is less liquidity stock market, high return projects may reduce investment.

Moreover, the interaction between adjustment of the exchange rate and stock prices depend on the increasing domestic interest rates resulting in capital inflows and exchange rate appreciation. It suggests that exchange rate appreciation has a negative effect on stock prices for export-led industries. These industries have appreciated their currencies due to reduced exports, and the increase in imports has led to the import of leading-edge stock markets (positive impact on stock prices). Concerning the interaction between stock prices and interest rates, much study has done in developed capital markets. The outcomes of most studies exhibit that stock and bond returns are easy to predict and the other. Investors tend to transfer stocks whenever the interest rate of government bonds rises, causing stock prices to fall (Menike, 2006).

Maskay (2007) attempted to analyze the connection between the adjustment of the money supply and stock market prices by using the two-level regression model to discover the connection between M2 and stock prices in 1959 Q1 to 2006 Q3. The empirical evidence found that there is a positive correlation between the supply of money and stock prices. Mohamadpour et al. (2012) examined the link between monetary policy and the performance of the stock market in Malaysia. They applied the Vector Error Correction Model (VECM) to test the correlation among monetary supply and the stock market. They found that the long-term relationship between M1, M2 and the stock market with highly significant. Kraft and Kraft (1997) attempted to test the connection between several determinants on stock prices. They use Granger Causality test to check the link between M1 and stock price. The empirical result found that M1 and stock price are not causally related. 
Also, the relationship between monetary policy and stock market prices in Nigeria has investigated by Jonathan and Oghenebrume (2017). They also use the model of error correction (ECM) to study the connection between money supply and the price of the stock market. The empirical result shows that broad money (M2) has a long-term positive interaction with stock market prices. M2 has a negative interaction with short-term stock market prices. There was once a negative connection with the money supply and the improvement of China's stock index thru negative correlation proved by Yong, 2004 (as cited in Širǔček, 2012). Praphan and Subhash (2002) found that excessive inflation in Indonesia and Philippines causes the long-term negative connection between stock prices and money supply, so inflation might also have a negative influence on money supply (as noted in Boonyanam, 2014).

Similarly, Suriani et al. (2015) attempted the link between the exchange rate and the stock market. They applied ADF to verify the unit-roots or stationarity level of the data. They also used Granger causality test to check whether both variables are independent or affect each other. The empirical findings showed that there is no relevance within the exchange rate and the stock market.

Thang (2009) explores the effect of the exchange rate and interest rate toward the stock market index in Malaysia. He applied ADF, VECM and unit root test. The finding outcome was that all the variables are stationary at first difference. The interest rate and real effective exchange rate have a negative influence on the stock market index for both the long and short run. Agrawal, Srivastav and Srivastava (2010) attempted to study the movement of exchange rates and volatility of the stock market in India. The study period is using daily closing indices from October 2007 to March 2009. They applied the normality test, unit root or stationarity, ADF and Granger Causality Test. The finding outcome shows that the currency rate and stock market were non-normally distributed and were stationary at the level from itself. There was negatively associated with both the stock market and exchange rate. They found there was one way causal among the stock market and exchange rates from the former towards the latter.

There are numerous researchers had observed the interaction among interest rate and the stock market. In line with Musawa and Mwaanga (2017), explore the effect of commodity prices, interest rate and exchange price toward the stock market. They used Autoregression Distribution lag, cointegration and VECM method to tested. The empirical result showed that interest rate, exchange rate, copper as well as oil prices have the long and short-term stock market impact together. Only the interest rate and the copper price had a significant effect on the stock market over the long term.

Maysami and Koh (2000) used the VECM method to test the long-term balance interaction with both randomly chosen macroeconomic variables and stock index in Singapore, Japan and the U.S. This Study was using monthly data from 1988 to 2003. The finding that they discovered changes in stock market level of Singapore resulted in a co-integration connection with price level, money supply, short and long-term interest rate and changes in exchange rates outside manufacturing production and distribution. They found that the stock market in Singapore co-integrated significantly and positively with the stock market in the U.S. and Japan.

In this study, we want to explore the effect of the interest spread between the United States and Malaysia on the stock market. An investor decides for investment in the stock market relies on the interest rate in the domestic stock market. The interest rate may have a positive or negative influence on the stock market. However, now, the stock market has a cointegrated global country. Investors are not only depending on the interest rate in the domestic market but also global country's market. Investors can compare the interest rate between two or more countries to make their decision for investment. Interest spread is the difference in the interest rate between the United States and Malaysia. In this research, we focus on the interest spread on the stock market.

The theoretical framework illustrates that independent variables affect dependent variables. The dependent variables are Stock Market Index in Malaysia (KLCI) while the independent variables are money supply (broad money), real effective exchange rate (REER) and interest spread between the United States and Malaysia. According to Lithman (2012) stated that in the previous study, the stock prices increase as interest rates fall as the money supply increase. However, the price of bonds and stocks moved oppositely. Wangbangpo and Sharma (2002) have cited in the previous studies pointed out these exchange rates and changes have an impact on stock market performance. Ma and Kao (1990) and Mekherjee and Naka (1995) argue that exchange rate depreciation to have a positive effect on domestic stock markets for dominant export countries (as cited in Wangbangpo \& Sharma, 2002). Interest spread has an impact on the stock market.

Moreover, in this study, the interest spread is focused on the spread between the two countries. An investor will decide whether to be able investment depends on the interest rate. However, this study, the investor also depends on the global country's market, not only the domestic market.

\section{RESEARCH METHODS \\ Source of data}

The study employs a time series of data and concerns on secondary data. Stock market index (KLCI) was collected from the DataStream, which is Thomson Reuters. Real effective exchange rate and interest spread was collected from International 
Financial Statistic. Money supply was collected from the global economy. The data are reliable. These are the common sources where the most of the people get the data from. The data of all the independent variables and dependent variable was collected on a monthly from January 1997 to August 2018.

\section{Specification of Model}

Based on the theory, characteristics of data and the objective of the research are related. The appropriate specification model is a unit root test, and Autoregressive distributed lag (ARDL) and Error Correction Model (ECM) to measure the first objective. Autoregressive distributed lag (ARDL) measures the long-term interaction between the money supply, exchange rate and interest spread on the stock market. While ECM describes how $\mathrm{y}$ and $\mathrm{x}$ comply with a long-term co-integrating relationship in the short run. The equation of the ARDL model to approach cointegration as below:

$$
\begin{aligned}
\Delta \text { LNKLCI }_{t}=\gamma_{0} & +\sum_{i=1}^{k} \gamma_{i} \Delta L N K L C I_{t-i} \\
& +\sum_{i=0}^{n} \gamma_{2 i} \Delta L N M S_{t-i} \\
& +\sum_{i=0}^{n} \gamma_{3 i} \Delta L N R E E R_{t-i} \\
& +\sum_{i=0}^{n} \gamma_{4 i} \Delta I S_{t-i}+\delta_{1} L N K L C I_{t-1} \\
& +\delta_{2} L N M S_{t-1}+\delta_{3} L N R E E R_{t-1} \\
& +\delta_{4} I S_{t-1}+w_{t}
\end{aligned}
$$

In the equation (1) LNKLCI-natural logarithm stock market index, LNMS-natural logarithm money supply, LNREER-natural logarithm real effective exchange rate, and IS-interest spread, $\mathrm{w}_{\mathrm{t}}$ means that error term. After that estimate the ECM with the equation as below:

$$
\begin{aligned}
\Delta \text { LNKLCI }_{t}=\propto_{0 i} & +\sum_{i=1}^{k} \propto_{i} \Delta L N K L C I_{t-i} \\
& +\sum_{\substack{n=0 \\
n}}^{n} \propto_{2 i} \Delta L N M S_{t-i} \\
& +\sum_{i=0}^{n} \propto_{3 i} \Delta L N R E E R_{t-i} \\
& +\sum_{i=0}^{n} \propto_{4 i} \Delta I S_{t-i}+\lambda E C_{t-1}+w_{t}
\end{aligned}
$$

The coefficient of $E C_{t-1}$ should be negative for series convergence to long-term equilibrium. In addition, the size of $E C_{t-1}$ represents the adjustment speed toward the balance. When $E C_{t-1}$ small which tends to -1 mean that the adjustment speed is fast while $E C_{t-1}$ is a large value which tends to 0 , mean that the adjustment is slow. Besides, the appropriate specification model to measure objective 2 is using the ARCH model and GARCH Model. GARCH Model is testing the volatility spillover effect between the money supply, exchange rate and interest spread on the stock market. Before the test of the GARCH model, we will test an ARCH model first. ARCH model is used to describe a changing, possibly volatility variance. The equation as below:

$$
\sigma_{t}^{2}=\lambda_{0}+\sum_{i=1}^{q} \lambda_{1} \varepsilon_{t-1}^{2}=\lambda_{0}+\lambda_{q}(\beta) \varepsilon_{t-1}^{2}
$$

The linear ARCH (q) for the conditional variance $\sigma_{\mathrm{t}}^{2}$. After the test the ARCH model, then we can proceed with the GARCH model. GARCH model is developed to improve on ARCH models by including a "smoothing- averaging" to produce a substantially more parsimonious specification. The equation of the $\operatorname{GARCH}(\mathrm{p}, \mathrm{q})$ model as below:

$$
\begin{aligned}
& \sigma_{\mathrm{t}}^{2}=\propto_{0}+\propto_{1} \varepsilon_{\mathrm{t}-1}^{2}+\propto_{2} \varepsilon_{\mathrm{t}-2}^{2}+\cdots+\propto_{\mathrm{q}} \varepsilon_{\mathrm{t}-\mathrm{q}}^{2}+ \\
& \beta_{1} \sigma_{\mathrm{t}-1}^{2}+\beta_{2} \sigma_{\mathrm{t}-2}^{2}+\beta_{\mathrm{p}} \sigma_{\mathrm{t}-\mathrm{p}}^{2}
\end{aligned}
$$

\begin{tabular}{|c|c|c|c|c|}
\hline \multirow[t]{2}{*}{ Variables } & \multicolumn{2}{|c|}{ Level } & \multicolumn{2}{|c|}{$\begin{array}{c}\text { First } \\
\text { differences }\end{array}$} \\
\hline & Intercept & $\begin{array}{l}\text { Intercept } \\
\text { and trend }\end{array}$ & Intercept & $\begin{array}{l}\text { Intercept } \\
\text { and trend }\end{array}$ \\
\hline LNKLCI & -1.29 & -4.80 & -13.33 & -13.36 \\
\hline LNMS & -1.12 & -0.48 & -14.58 & $-14.60 *$ \\
\hline LNREER & -4.44 & -4.36 & -13.96 & -14.00 \\
\hline IS & $-2.998^{*}$ & -5.59 & -4.35 & -4.448 \\
\hline
\end{tabular}

Note that the coefficient $\beta_{\mathrm{j}}$ represents the weight or impact of previous conditional variance. These have on the current conditional variance. The sum of

\begin{tabular}{|c|c|c|c|c|}
\hline \multirow[t]{2}{*}{ Variables } & \multirow{2}{*}{ Intercept } & \multirow{2}{*}{$\begin{array}{l}\text { Level } \\
\text { Intercept } \\
\text { and trend }\end{array}$} & \multicolumn{2}{|c|}{ First differences } \\
\hline & & & Intercept & $\begin{array}{l}\text { Intercept } \\
\text { and } \\
\text { trend }\end{array}$ \\
\hline LNKLCI & -1.22 & -4.37 & -13.29 & -13.36 \\
\hline LNMS & -1.01 & -0.78 & -14.68 & -14.70 \\
\hline LNREER & -3.96 & $-3.91 * *$ & -13.97 & -14.01 \\
\hline IS & -2.10 & -2.53 & -24.66 & -24.62 \\
\hline
\end{tabular}
$\propto_{\mathrm{q}}$ and $\beta_{\mathrm{p}}$ measures the persistence of volatility.

\section{RESULTS AND DISCUSSION}

The data analyzing a method for this study will be started with the unit root test. After a series of periods tested with the stationary, the cointegration test was conducted using the 'autoregressive distributed lags' (ARDL) approach populated by Pesaran et al. (2001).

Table 1. Result of the Augmented Dickey-Fuller (ADF) test for unit root significantly at $1 \%$

Table 2. Results of Phillips-Perron (PP) test significantly at $1 \%$ and $* *$ for $5 \%$ 
Based on Table 1 and Table 2, results from ADF and PP stunt testing indicate that the data is still mixed between I (0) and I (1). Therefore, the ARDL modelling approach is suitable for the model.

\section{Co-integration test}

The next analysis was to determine the existence of long term cointegration relations between the stock market index (LNKLCI) and exogenous variables (LNMS, LNREER, and IS). Results in Table 3 show that statistical value $\mathrm{F}$ for the model is higher than the upper bound value, I(1) and this show that the cointegration exists between the variables in the model.

Table 3. Results of the cointegration test

\begin{tabular}{lccc}
\hline F-Statistic & Significant & $\mathrm{I}(0)$ & $\mathrm{I}(1)$ \\
\hline F-statistic & $10 \%$ & 2.72 & 3.77 \\
& $5 \%$ & 3.23 & 4.35 \\
F-statistic value & & 8.587313 & \\
\hline
\end{tabular}

Notes: Critical values for the bounds test: case III: unrestricted intercept and no trend.

\section{Long-Run Analysis}

Table 4. Results for the coefficient of long run

\begin{tabular}{cccc}
\hline Variables & \multicolumn{3}{c}{ LNKLCI } \\
& Coefficient & $\begin{array}{c}\text { Standard } \\
\text { Error }\end{array}$ & t-Statistic \\
& & 0.059 & 14.463 \\
& $0.857 * * *$ & 0.441 & 2.014 \\
LNMS & $0.888^{* *}$ & 0.015 & -2.435 \\
LNEER & $-0.036^{* *}$ & 0.359 & -1.178 \\
IS & -0.423 & 0.359
\end{tabular}

Serial Correlation Value (LM's test) $=0.2464$

Notes: * Significant at 10\%,** Significant at 5\% and *** Significant at $1 \%$. The entire variables are natural logarithm except IS and $C$ is constant.

Table 4 shows the long term coefficient of ARDL model with optimum lag is ARDL $(2,2,1,2)$. The optimum lag value is decided based on Akaike Info Criterion (AIC). In general, the diagnostic test for the model produces good results. It clearly shows that these models are free from serial correlation. The long term coefficient results clearly show that LNMS, LNREER and IS play an essential role in influencing stock market index (LNKLCI). LNREER and IS is statistically significant at least at 5 per cent. LNMS is significant at 1 per cent. The result of this study is consistent with the previous research. Alam and Uddin (2009) stated that interest rate has significant negative relationship with share price. Rasiah and Ratnswary (2010) found that positive long run relationship between money supply, real exchange rate and real stock returns. According to Masood and Sarwar (2015) found that exchange rate and money supply are positive determinants of stock price in Pakistan. There are stable long run co-integration between stock price and macroeconomic variables.

\section{Short Run Analysis}

Table 5. Result of Error Correction Model (ECM) and Coefficient of short run

\begin{tabular}{lccc}
\hline \multicolumn{1}{c}{ Variables } & Coefficient & $\begin{array}{c}\text { Standard } \\
\text { Error }\end{array}$ \\
\hline C & $-0.423 * * *$ & 0.070 & -5.975 \\
D(LNKLCI(- & $0.170 * * *$ & 0.056 & 3.016 \\
1)) & & & \\
D(LNMS) & $1.287 * * *$ & 0.439 & 2.931 \\
D(LNMS(-1)) & 0.707 & 0.437 & 1.619 \\
D(LNREER) & $0.916 * * *$ & 0.188 & 4.865 \\
D(IS_MM) & -0.005 & 0.006 & -0.395 \\
D(IS_MM(-1)) & $-0.011 *$ & 0.006 & -1.712 \\
ECM(-1)* & $-0.149 * * *$ & 0.025 & -5.896 \\
\hline Notes: * significant at 10\%, **significant at 5\% and ***
\end{tabular}

significant at $1 \%$.

According to Engle and Granger (1987), the error correction model (ECM) is a short term model with long term information. The error correction value in the model is negative and significant at the level of 1 per cent. The empirical results show the 14.9 per cent of departures from long-run equilibrium is corrected each period. Therefore, there was a low speed of adjustment.

\section{The volatility of Bank's Performance}

Table 6 shows the result of the GARCH $(1,1)$. In the top section is the mean equation. It shows that the average return is -4.2921 . All the variables are significant at 1 per cent. The lower section is the variance equation that gives the result of the $\mathrm{ARCH}$ model, namely that the time-varying volatility includes a connected component (0.0004) plus a component which depends on past errors (1.0036). The $\operatorname{resid}(-1)^{\wedge} 2$ is significant at 1 percent. The GARCH also significant at 1 percent. These results show that the volatility coefficient, the one ARCH effect (1.0036) and the one in front of the GARCH effect is (0.1739) are both positive. The volatility persistence indicates by (RESID (-1)^ $2+$ GARCH (1)) was 1.1777 , respectively indicating high persistence and volatility shock is large.

Table 6. Results of $\operatorname{GARCH}(1,1)$

\begin{tabular}{llll}
\hline \multicolumn{1}{c}{ Variables } & Coefficient & $\begin{array}{c}\text { Standard } \\
\text { Error }\end{array}$ & Z-statistic \\
\hline LNMS & $0.90 * * *$ & 0.01 & 134.37 \\
LNREER & $1.15 * * *$ & 0.06 & 20.48 \\
IS_MM & $-0.04 * * *$ & 0.01 & -17.82 \\
$\mathrm{C}$ & $-4.29 * * *$ & 0.28 & -15.38 \\
\multicolumn{4}{c}{ Variance Equation } \\
$\mathrm{C}$ & $0.01 *$ & 0.01 & 1.90 \\
$\mathrm{RESID}(-1)^{\wedge} 2$ & $1.01 * * *$ & 0.18 & 5.46 \\
GARCH(-1) & $0.18 * * *$ & 0.07 & 2.63 \\
\hline \multicolumn{2}{l}{ Notes: $*$ significant at 10\%, ** significant at 5\% and $* * *$} \\
significant at 1\%.
\end{tabular}

Figure 1 shows the line graph of conditional variance for GARCH $(1,1)$. In 1997 to 2000, the volatility is very high. It is because the Asian financial crisis causes the volatility of the stock market high. As 
we can see 2007 to 2008 , the volatility was not much that high even though that happens the financial crisis in 2008. It compares to the Asian financial crisis. From 2010 to 2018, there is low volatility. It can conclude that when happen, the financial crisis it will lead the stock market has high volatility.

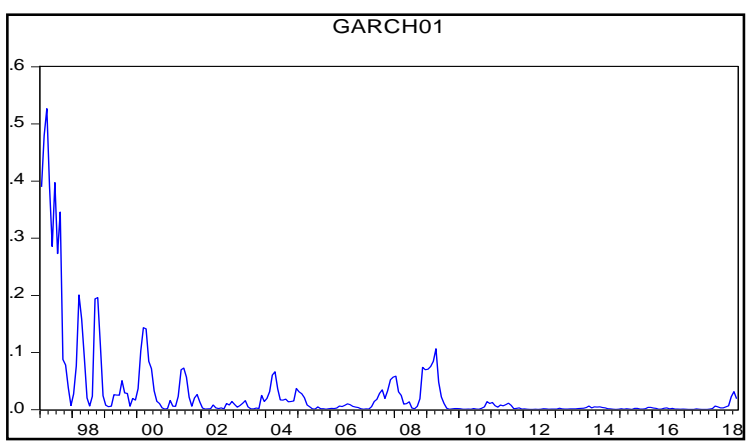

Figure 1. Conditional variance for $\operatorname{GARCH}(1,1)$

\section{Diagnostic checking}

Table 7 shows the result of Breusch-Codfrey Serial Correlation LM test for the ARDL model. The result shows that the probability Chi-Square for obs* $\mathrm{R}$-squared is 0.2464 . It indicates that there is larger than the significant of 5 per cent. It fails to reject the null hypothesis, which is that there is no autocorrelation.

Table 7. Results of Breusch-Godfrey Serial Correlation LM Test

\begin{tabular}{lclc}
\hline \multicolumn{4}{l}{ Breusch-Godfrey Serial Correlation LM Test: } \\
\hline F-statistic & 1.345 & Prob F(2,245) & 0.262 \\
$\begin{array}{l}\text { Obs*R- } \\
\text { squared }\end{array}$ & 2.802 & $\begin{array}{l}\text { Prob. Chi- } \\
\text { Square(2) }\end{array}$ & 0.246 \\
\hline
\end{tabular}

The Figure 2 shows that the CUSUM curve remains within the critical 5 per cent range, which confirms the long term relationship between the variables, thus, showing the stability of the coefficient. Based on the discussion of the results of the diagnostic tests made, the established model did not experience autocorrelation problems, which could results in a problematic error in the model. Looking at CUSUM test results, the error generated from the alltime series included in the model was relatively stable, and the time series data involved in this study were identified to have no structural changes.

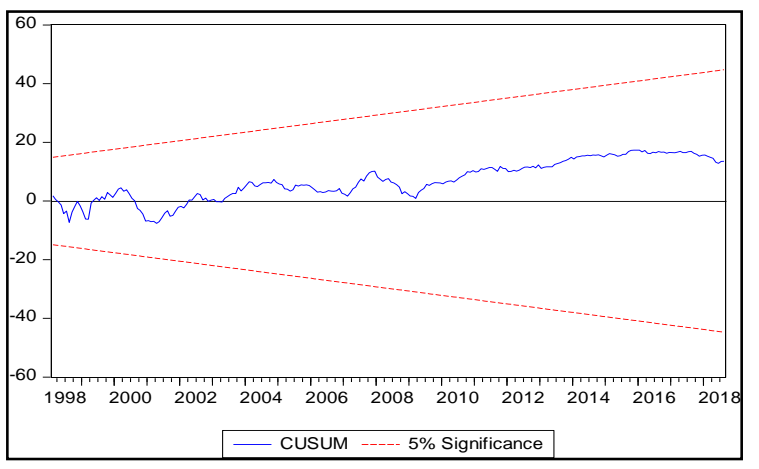

Figure 2. CUSUM Test
The Table 8 shows the result of ARCH LM test for GARCH model. As a result shows the probability chisquare is 0.4341 , which is larger than the significance of 5 per cent. It indicates that fail to reject the null hypothesis, which is there is no ARCH effect.

Table 8. Results of Heteroscedasticity Test: ARCH

\begin{tabular}{|c|c|c|c|}
\hline \multicolumn{4}{|c|}{ Heteroscedasticity Test: ARCH } \\
\hline F-statistic & 0.608 & Prob F(1,257) & 0.436 \\
\hline $\begin{array}{l}\text { Obs*R- } \\
\text { squared }\end{array}$ & 0.612 & $\begin{array}{l}\text { Prob. Chi- } \\
\text { Square(1) }\end{array}$ & 0.434 \\
\hline
\end{tabular}

Table 9 shows the results of the normality test. The probability of Jarque-Bera is 0.0279 , which is smaller than the significant $5 \%$. It implies that reject the null hypothesis, which is there is normally distributed.

Table 9. Results of normality

\begin{tabular}{ll}
\hline Normality test & \\
\hline Jarque-Bera & 7.155 \\
Probability & 0.028 \\
\hline
\end{tabular}

\section{CONCLUSSION}

In conclusion, the money supply and stock market performance are a positive relationship. So government and policymaker can refer to this study as references. Government and policymaker can stabilize stock market performance by adjusted the monetary policy when the impact of money supply on the stock market. An expanding monetary policy has spurred the economy, the cash flow in the hands of public increase and this led the demand of stocks and other assets also increased. Upon translation of these needs into actual purchases, stock prices may rise. Besides that, growth in money also affects stock prices and interest rates.

Moreover, to improve the performance of the stock market, government and policymaker can implement fiscal policies. When the exchange rate is weak, the stock market performance is better. It is important information for the government to monitor economic growth. This study provided information for local and foreign investors. In this study for interest spread, it depends on the interest rate between two countries. Investor not only depends on the domestic interest rate and also interest rate in other countries. This information can use to make investment decision more accurate. With an understanding between the real effective exchange rate and the stock market, investors can appropriate transactions to achieve their investment objective.

The first limitation is that there is a lack of the previous study done by another researcher, which is the impact of interest spread on the stock market. In this study, the spread focus on the two countries. Therefore, this is very limited to research that can be used as main references. Most of the previous study is conducted by using the domestic interest rate variable. There is arising the limited data for interest spread (interest rate). The constraint is there is no much same 
indicator for Malaysia and the United States that provided completed data by month to month. Therefore, it is only limited to this research because of the data collection constrain.

One of the recommendations to future researchers is that they can apply panel data. It is because panel data can compare with other countries and the period. The researcher can compare with Asian countries such as Thailand, Singapore, Indonesia and others. The impact of interest spreads on the stock market in different countries by comparing interest spread factors. So investors will get more information that can help them make decisions on investment. Besides, it is recommended that researchers use daily data to track the stock market movement. It is because daily data is more accurate than monthly data.

\section{REFERENCES}

Alzaid, S. (2016). The Kuala Lumpur stock exchange composite index (KlSE CI) and economic forces. South-East Asia Journal of Contemporary Business, Economics and Law, 10(3), 53-64.

Ambunya, P. L. (2012). The relationship between exchange rate movement and stock market returns volatility at the nairobi securities exchange. Masters of Business Administration (MBA) Project School of Business, University of Nairobi.

Aslam, W. (2014). Relationship between stock market volatility and exchange rate: a study of KSE. Journal of Public Administration, Finance and Law, (5), 62-72.

Bahmani-Oskooee, M. \& Sohrabian, A. (1992). Stock prices and the effective exchange rate of the dollar. Applied Economics, 24(4), 459-464. Doi:10.1080/00036849200000020

Boonyanam, N. (2014). relationship of stock price and monetary variables of asian small open emerging economy: evidence from Thailand. International Journal of Financial Research, 5(1), 52.

Brahmasrene, T. \& Jiranyakul, K. (2007). Cointegration and Causality between Stock Index and Macroeconomic Variables in a Emerging Markets. Academy of Accounting And Financial Studies Journal.

Chan, Audery. (2014). Impacts of crude oil price \& money supply on stock price: the case of Malaysia. doi:10.13140/2.1.3305.6000.

Cheng, L.S., Goh, H.Y.,Ong, J.L.H., Lai, C.Y. \& Yong, S.Y. (2013). Impact of macroeconomic variables on stock market development: evidence from Malaysia.

El Wassal, K. A. (2013). The development of stock markets: In search of a theory. International Journal of Economics and Financial Issues, 3(3), 606-624.
Garcia, V. F. \& Liu, L. (1999). Macroeconomic determinants of stock market development. Journal of Applied Economics, 2(1).

Gujarati, D. N. \& Porter, D. C. (2003). Basic Econometrics. 4th.

Jonathan, O. O. \& Oghenebrume, A. D. (2017). Impact of monetary policy on stock market prices in Nigeria. Journal of Economics, Management and Trade, 19(4): 1-11.

Khan, K., Qingyang, W., \& Khurshid, A. (2017). Causal relationship between monetary policy and the stock market: a bootstrap rolling window approach.

Khan, T. A. (2011). Cointegration of international stock markets: An investigation of diversification opportunities. Undergraduate Economic Review, 8(1), 7.

Kraft, J. \& Kraft, A. (1977). Determinants of common stock prices: a time series analysis. The Journal of Finance, 32(2), 417. doi:10.2307/2326775.

Li, Y. (2012). Empirical study on the relationship between money supply and stock market in Europe. In International Conference on Information Computing and Applications (pp. 539-544). Springer, Berlin, Heidelberg.

Lithman, O. K. E. (2012). Money supply and stock prices.

Maskay, B. (2007). Analyzing the effect of change in Money supply on stock prices. The park place economist, 15(1), 72-79.

Maskay, B. \& Chapman, M. (2007). Analyzing the relationship between change in money supply and stock market prices. Illinois Wesleyan University Economics Department.

Masood, S. \& Sarwar, S. (2015). Relationship between Stock Prices and Exchange Rate: A bivariate and multivariate analysis from Pakistan's economy. International Affairs and Global Strategy, 32, 9-27.

Maysami, R. C. \& Koh, T. S. (2000). A vector error correction model of the Singapore stock market. International Review of Economics \& Finance, 9(1), 79-96.

Maysami, R. C., Lee, C. H., \&Hamzah, M. A. (2004). Relationship between macroeconomic variables and stock market indices: Cointegration evidence from stock exchange of Singapore's all-S sector indices. Jurnal Pengurusan, 24(2004), 47-77.

Menike, L. M. C. S. (2006). The effect of macroeconomic variables on stock prices in emerging Sri Lankan stock market. Sabaragamuwa university journal, 6(1), 50-67.

Mohamadpour, B., Behravan, N., Espahbodi, S. \& Karimi, R. (2012). An empirical study of relationship between monetary policy and stock market performance in Malaysia. Australian Journal of Basic \& Applied Sciences, 6(12), 142-148. 
Musawa, N., \& Mwaanga, C. (2017). The impact of commodity prices, interest rate and exchange rate on stock market performance: evidence from Zambia. Journal of Financial Risk Management, $\quad$ 6, 300-313. https://doi.org/10.4236/jfrm.2017.63022

Nordin, S., Nordin, N., \& Shahimi, W. R. (2016). Malaysian Stock Market: A Spur to the Country's Economic Growth. China-USA Business Review,15(02).doi:10.17265/15371514/2016.02.001

Rahman, A. A., Sidek, N. Z. M. \& Tafri, F. H. (2009). Macroeconomic determinants of Malaysian stock market. African Journal of Business Management, 3(3), 095-106.

Širůček, M. (2012). Effect of money supply on the Dow Jones Industrial Average stockindex. Acta Universitatis Agriculturae et Silviculturae Mendelianae Brunensis, 60(2), 399-408.

Sirucek, M. (2012). The impact of money supply on stock prices and stock bubbles.

Suriani, S., Kumar, M. D., Jamil, F. \& Muneer, S. (2015). Impact of exchange rate on stock market. International Journal of Economics and Financial Issues, 5(1S), 385-388.

Thang, F. Z. (2009). Impact of Interest Rate and Exchange Rate on the stock market index in Malaysia: A cointegration analysis. Unpublished master's thesis, Universiti Sains, Penang, Malaysia. Retrieved from http://eprints. usm. my/25494/1/IMPACT_OF_INTEREST_RATE _AND_EXCHANGE_RATE_ON.pdf.

Wong, W.K., Khan, H. \& Du, J. (2005). Money, interest rate, and stock prices: new evidence from Singapore and The United States. National University of Singapore Department of Economics, No. 007, pp. 3-30.

Wongbangpo, P., \& Sharma, S. C. (2002). Stock market and macroeconomic fundamental dynamic interactions: ASEAN-5 countries. Journal of Asian Economics, 13(1), 27-51. 